\title{
Brand Management Practices, Corporate Image and Customer Satisfaction Among University Students in Kenya. Testing the Moderating Effect of Corporate Image
}

\author{
Authors: Stephen Maore Prof Justus Munyoki Prof Mary Kinoti Dr Joseph Owino \\ School of Business, University of Nairobi, P.O BOX 3019700100 Nairobi, Kenya
}

\begin{abstract}
This study sought to establish the mediating effect of corporate image on the relationship between brand management practices and customer satisfaction among universities in Kenya. The study adopted descriptive research design, the target population comprised of students from all 70 universities registered and accredited to operate in Kenya, with a population of 443,783 students enrolled for various undergraduate degree programmes from which a sample of 384 students was drawn. Data was analyzed using a combination of four different statistical analysis methods that included descriptive statistical analysis, factor analysis, correlation analysis and regression analysis. The study also established that corporate image had a significant mediating effect on the relationship between brand management practices and customer satisfaction with $\mathrm{R}^{2}=0.388$; $\mathrm{p}$-value $=0.000$. Brand management practices were found to influence customer satisfaction more in the private individual owned and private institutional owned than in public universities, with R square of $0.149,0.312$ and 0.423 respectively. Similarly, corporate image was found to have a stronger moderation effect on the relationship between brand management practices and customer satisfaction in private institutional owned universities as compared to the private individual owned and public universities, with $\mathrm{R}^{2}$ of $0.671,0.440$ and 0.213 respectively. The study recommends that policy can be developed that encourages inculcating brand management practices within universities in Kenya. Policy can be developed to encourage measurement and reporting of performance along brand management practices as used in this study.
\end{abstract}

Keywords: Branding, Brand Management, customer satisfaction, universities, brand image.

DOI: $10.7176 / \mathrm{EJBM} / 11-2-03$

\section{Introduction}

Brand management is the analysis, planning and implementation of branding strategies intended to influence the market perception towards a product or service. For effective branding, it is important to establish a cordial relationship with the customers. According to Keller (2001), brand management practices include brand positioning (the place a product occupies in the mind of the relative to substitutes); brand identity (the noticeable elements that give a brand a distinction from the rest; brand personality (the human personality traits or characteristics that are assigned to a brand); and brand recognition (ability of a consumer to identify a brand positively through its logo, tag line, package or design).

According to Kapferer (2008), brand identity refers to the meaning attributed to a brand from the owner's perspective. Similarly, Aaker (1991) supports that brand identity refers to how the organization see itself whereas brand image represents how others see the organization. According to Kotler and Keller (2012), brand positioning refers to the act of designing a brand to occupy a distinct place in consumers' mind. This may be based on tangible and intangible attributes that are associated with the brand. Aaker (1997) argues that the strength of a brand will depend on the extent to which a consumer can positively identify a particular product or service without any aid, by just viewing the product logo, slogan, package or advert, a concept referred to as brand recognition. It is measured by the consumers' ability to recall a brand when exposed to some cues such as the name, package, color, design. Another major element of brand management is brand personality. Keller (2001) points out that if a brand consistently offers positive experiences over many years of regular use, it acquires a human like characteristics. In Kenyan context, due to increased competition, stringent regulations and a well-informed population due to technological advancement, most local and foreign universities are investing more in brand building initiatives to enhance their competitiveness. For example, the University of Nairobi has enhanced her marketing and positioning strategy through increased promotion, advertisement in the local media and online platforms. Other public and private universities have followed suit.

Bravo, Montaner and Pina (2009), defines corporate image as the mental picture in the customer's mind as a result of continued interaction with the brand. They are stored in the memory, retrieved to reconstruct image, transformed into either positive or negative meaning, and retrieved when the name of the organization is mentioned. Corporate image consists of a functional and emotional component. The functional components are the tangible characteristics or physical components that are easily measurable, such as brand architecture and brand portfolio (Waithaka, 2014). On the other hand, the emotional component is the psychological feelings, towards an organization that could be attributed to consequences from past accumulated experiences and 
associations with the organization (Kandampully \& Hu, 2007).

Nguyen and Leblanc (2001) argue that due to the intangibility nature of services, management of corporate image is a challenging task. A positive corporate image can add value to a firm in many ways that gives a firm a competitive edge in the market place. On the other hand, a negative image can destroy an organization's reputation and influence the customers' perception towards the brand. They further pointed out that there is a strong relationship between corporate image and the physical and behavioral attributes of a firm, such as the business name, architecture, product portfolio, tradition, ideology and the impression of quality communicated by each person interacting with an organization's clients. In general, corporate image is a critical factor in the overall evaluation of an organization's strength and attractiveness in the industry.

According to Owino (2013), customer satisfaction measurement should include the ability to understand the gap between expectation and performance of the HEIs. From a students' vantage position, branding does solve many purchase decisions, serving to deliver a promise to help facilitate decision making and final selection of the university to apply and attend (Makgosa \& Molefhi, 2012). However, due to the intangibility nature of education services, it is difficult to measure the level of satisfaction in before consumption occurs (Makgosa \& Molefhi, 2012). Higher Education sector provides rich context for research on branding as Kenyan institutions are becoming increasingly marketing oriented and students increasingly being perceived as more informed consumers (Mourad, Ennew \& Kortam 2011). The increased competition has pushed the universities to identify a unique selling point on which to position their brands. For the purpose of this study, customer satisfaction was defined as the resultant effect achieved when students (customers) evaluates their overall encounter with the university as they receive the services.

The main objective of this study was to establish the influence of brand management practices and corporate image on customer satisfaction among universities in Kenya. It sought to test the following hypothesis: $\mathrm{H}_{1}$ : There is a significant relationship between brand management practices and customer satisfaction among universities in Kenya.

$\mathrm{H}_{2}$ : Corporate image significantly mediates the relationship between brand management practices and customer satisfaction among universities in Kenya.

\section{Literature Review}

The study was anchored on two main theories; the customer based brand equity model and the expectation confirmation theory. Brand equity can be conceptualized from the consumer's point of view. According to Aaker (1991) and Keller (1993), consumers responses to marketer's' offerings differ from one consumer to another depending on their level of knowledge, attitude, and overall perception towards the brand. As consumers interact with a brand, they develop both positive and negative associations with the brand, which culminates to assets and liabilities that generates value to a firm or its customers (Aaker, 1997). CBBE model is based on the assumption that the value of a brand is determined by the consumer rather than the brand proprietor. Consumer judgment is based on various cues name, package, color, design, prior experience, and word of mouth among other internal and external brand attributes.

Oliver (1997) posits that satisfaction is directly influenced by the rate at which product/service perceived performance meets customer expectations. The consumer evaluates the overall performance to confirm whether or not their expectations are met. From this evaluation, a consumer will be either satisfied or dissatisfied (Spreng, MacKenzie \& Olshavsky, 1996). Jiang and Klein (2009) argue that this theory can be applied in different contexts where satisfaction is a dependent variable. From a branding perspective, consumers who form a positive disconfirmation about a brand are more likely to remain loyal and develop a positive or a negative association towards a brand. In the context of universities in Kenya, students may form disconfirmation based on their perceived expectations before they joined the university.

Corporate image refers to the beliefs and impressions that the community and other stakeholders make about an organization. It is a notion held by others about a particular organization, which helps the institution obtain superior status in a competitive environment (Kotler \& Armstrong, 2008). According to Owino (2013), corporate image in a university is the overall feelings. Thoughts, attitudes, impressions and knowledge held by stakeholders about the institution. Marketers of these institutions employ brand building activities such as brand identity, positioning and associations help in shaping the corporate image in the mind of the consumer (Keller, 1993). He further argues that the overall judgment of the brand performance is highly influenced by the prior knowledge and expectations that are formed through branding, hence influencing the overall satisfaction.

The marketing and branding activities carried out by universities as well as publicity and word of mouth communication among the students and other stakeholders increases the brand awareness of the institution (Mourad et al., 2011). In this respect, institutions of higher learning are willing to allocate substantial resources branding and promoting their products and services in an effort to create awareness and build a competitive advantage. Vukasovic (2015) further notes that promotional activities cover all promotions done by higher education institutions with an aim of creating a favorable image and goodwill among the students. A study 
carried out by Andreassen and Lindestad (1998) established that corporate image plays a critical role in influencing customer overall evaluation of quality and satisfaction with a brand. The attributes related to quality of university education, such as class size, faculty qualification, library services, access to learning materials among others, have been used as determinant of brand equity among the institutions of higher learning and thus the main strategy adopted by the universities to attract students.

According to Mourad, Gaese and Jabarin (2010) the brand quality attributes can be categorized into three components; provider, product and symbolic attributes. Provider attributes represents the internal publics, institution location, student faculty ratio among others. Product attributes refers to those specifically related to quality of the service such as tuition fees, customer service, courses offered, duration of study, admission criteria, graduate employability among others. Lastly but not the least, symbolic attributes refers to the associations related to the brand identity, overall image, innovation, institutional linkages among others (Vukasovic, 2015), This implies that brand management practices that are directed towards building a strong corporate image are likely to lead to customer satisfaction. For example, a brand with a unique identity, unique positioning or positive association translates to positive corporate image, hence satisfaction.

\section{Conceptual Model}

Figure 1 below demonstrates the relationship between independent variable (brand management practices) and dependent variable (customer satisfaction) with corporate image as the mediating variable.

Independent Variable

Brand
Management
Practices
- Brand identity
- $\quad \begin{aligned} & \text { Brand } \\ & \text { positioning and } \\ & \text { association }\end{aligned}$
- Brand
Recognition
Brand
personality

Source: Author, 2018

Figure 1: Conceptual model
Dependent Variable

$$
\begin{aligned}
& \text { Customer Satisfaction } \\
& \text { Overall satisfaction } \\
& \text { with the university } \\
& \text { services and processes } \\
& \text { (fees, class size, staff, } \\
& \text { library etc.) } \\
& \text { Willingness to enroll } \\
& \text { more courses in the } \\
& \text { university } \\
& \text { Recommend the } \\
& \text { university to others } \\
& \text { Willingness to talk } \\
& \text { positively about the } \\
& \text { university } \\
& \text { Positive attitude } \\
& \text { towards the university }
\end{aligned}
$$

\section{Research Methodology}

To effectively measure the relationship between the dependent and independent variables, this study adopted a descriptive cross sectional survey design. The target population for this study was undergraduate university students in Kenyan local universities. The study used a multistage sampling procedure that involved two stages. The first stage was sampling $30 \%$ of the universities in each category using a simple random sampling method. Since the categories were established, the researcher developed a source list from which 21 universities representing $30 \%$ of the target population was picked using random sampling. According to Mugenda and Mugenda (1999), at least $30 \%$ of the cases per group are required for research. A number was given to every university this was written on pieces of papers and placed in a container, folded and shuffled. A number was picked at a random. The process was repeated until the required sample of 384 students was attained.

The second stage used systematic random sampling, selecting every 5th student entering the main gate of the main campus of the selected university. Purposeful sampling was applied strategically to ensure equitable distribution of respondents based on gender, the program enrolled and the year of study. This helped reduce biasness and ensured fair representation. To arrive at the sample size of the university students, the researcher utilized Krejcie and Morgan (1970) sample size determination table.

Table 1: Sample Size

\begin{tabular}{lccccc}
\hline \multicolumn{1}{c}{ Strata } & $\begin{array}{c}\text { No. of } \\
\text { Universities }\end{array}$ & $\begin{array}{c}\text { Percentage } \\
\mathbf{\%}\end{array}$ & $\begin{array}{c}\text { Sample } \\
\text { size }\end{array}$ & $\begin{array}{l}\text { Percentage } \\
\mathbf{( 3 8 4 / 2 1} \\
* \mathbf{1 0 0 \%})\end{array}$ & $\begin{array}{l}\text { Sample } \\
\text { Size }\end{array}$ \\
\hline $\begin{array}{l}\text { Public Universities } \\
\text { Private Individual owned Universities }\end{array}$ & 33 & 30 & 10 & 18.29 & 183 \\
$\begin{array}{l}\text { Private Institutional } \\
\text { owned universities }\end{array}$ & 18 & 30 & 5 & 18.29 & 91 \\
Total & $\mathbf{7 0}$ & 30 & 6 & 18.29 & 110 \\
\hline
\end{tabular}

Source: Commission for University Education (2015) 


\section{Study Findings}

The study sort to establish the demographic characteristics of the respondents, this included, the age, gender, Nationality, residence, employment status, program enrolled, mode of study and year of study.

The study sought to establish the age of the respondents to ascertain the age bracket majority of the University students who participated in the study.

Table 2: Age of the respondents

\begin{tabular}{lcc}
\hline & Frequency & Percentage (\%) \\
\hline Under 20 years & 37 & 11.5 \\
20-24 years & 188 & 57.8 \\
25-29 years & 53 & 16.4 \\
30-34 years & 31 & 9.6 \\
35-39 years & 11 & 3.3 \\
40 years and above & 5 & 1.4 \\
Total & $\mathbf{3 2 5}$ & $\mathbf{1 0 0 . 0}$ \\
\hline
\end{tabular}

Source: Researcher (2018)

Table 2 shows that out of the 325 respondents, 188 (57.8\%) were aged between 20 and 24 years, 53 (16.4\%) were aged between 25 and 29 years, 11 (3.3\%) were aged between $35-39$ years while $5(1.4 \%)$ were aged above 40 years. This demonstrates the general distribution of students in undergraduate programs across universities, where majority are fresh high school graduates and minority being the mature working students.

All the constructs of the brand management practices were subjected to factor analysis and the results presented in Table 4.2 .

Table 3: Factor Analysis for Brand Management Practices

\section{KMO and Bartlett's Test}

Kaiser-Meyer-Olkin Measure of Sampling Adequacy.

Bartlett's Test of Sphericity

Approx. Chi-Square

df

Sig.
.954

7387.989

465

.000

\begin{tabular}{|c|c|c|c|c|c|c|c|c|c|}
\hline \multicolumn{10}{|c|}{ Total Variance Explained } \\
\hline \multirow[b]{2}{*}{ Component } & \multirow[b]{2}{*}{ Total } & \multirow{2}{*}{\multicolumn{2}{|c|}{$\begin{array}{l}\text { Initial Eigenvalues } \\
\quad \% \text { of }\end{array}$}} & \multicolumn{3}{|c|}{$\begin{array}{c}\text { Extraction Sums of Squared } \\
\text { Loadings } \\
\% \text { of }\end{array}$} & \multicolumn{3}{|c|}{$\begin{array}{c}\text { Rotation Sums of Squared } \\
\text { Loadings }\end{array}$} \\
\hline & & & & Total & $\begin{array}{c}\% \text { of } \\
\text { Variance }\end{array}$ & Cumulative \% & Total & $\begin{array}{c}\% \text { of } \\
\text { Variance }\end{array}$ & Cumulative \% \\
\hline 1 & 15.422 & 49.748 & 49.748 & 15.422 & 49.748 & 49.748 & 5.494 & 17.722 & 17.722 \\
\hline 2 & 1.635 & 5.276 & 55.024 & 1.635 & 5.276 & 55.024 & 4.749 & 15.320 & 33.042 \\
\hline 3 & 1.245 & 4.018 & 59.042 & 1.245 & 4.018 & 59.042 & 4.294 & 13.853 & 46.895 \\
\hline 4 & 1.182 & 3.812 & 62.854 & 1.182 & 3.812 & 62.854 & 4.075 & 13.146 & 60.041 \\
\hline 5 & 1.106 & 3.567 & 66.421 & 1.106 & 3.567 & 66.421 & 1.978 & 6.380 & 66.421 \\
\hline 6 & .848 & 2.734 & 69.156 & & & & & & \\
\hline 7 & .805 & 2.598 & 71.754 & & & & & & \\
\hline 8 & .786 & 2.535 & 74.289 & & & & & & \\
\hline 9 & .704 & 2.272 & 76.561 & & & & & & \\
\hline 10 & .657 & 2.121 & 78.681 & & & & & & \\
\hline 11 & .595 & 1.921 & 80.602 & & & & & & \\
\hline 12 & .490 & 1.582 & 82.184 & & & & & & \\
\hline 13 & .467 & 1.506 & 83.690 & & & & & & \\
\hline 14 & .459 & 1.482 & 85.172 & & & & & & \\
\hline 15 & .417 & 1.346 & 86.518 & & & & & & \\
\hline 16 & .382 & 1.233 & 87.751 & & & & & & \\
\hline 17 & .381 & 1.228 & 88.979 & & & & & & \\
\hline 18 & .361 & 1.164 & 90.143 & & & & & & \\
\hline 19 & .333 & 1.075 & 91.217 & & & & & & \\
\hline 20 & .325 & 1.048 & 92.266 & & & & & & \\
\hline 21 & .313 & 1.011 & 93.277 & & & & & & \\
\hline 22 & .275 & .888 & 94.165 & & & & & & \\
\hline 23 & .269 & .866 & 95.031 & & & & & & \\
\hline 24 & .252 & .812 & 95.843 & & & & & & \\
\hline 25 & .230 & .741 & 96.584 & & & & & & \\
\hline 26 & .227 & .732 & 97.316 & & & & & & \\
\hline 27 & .197 & .636 & 97.953 & & & & & & \\
\hline 28 & .188 & .606 & 98.559 & & & & & & \\
\hline 29 & .169 & .544 & 99.103 & & & & & & \\
\hline 30 & .149 & .480 & 99.583 & & & & & & \\
\hline 31 & .129 & .417 & 100.000 & & & & & & \\
\hline Extraction M & od: Prin & ccipal Comp & ent Analysis. & & & & & & \\
\hline
\end{tabular}




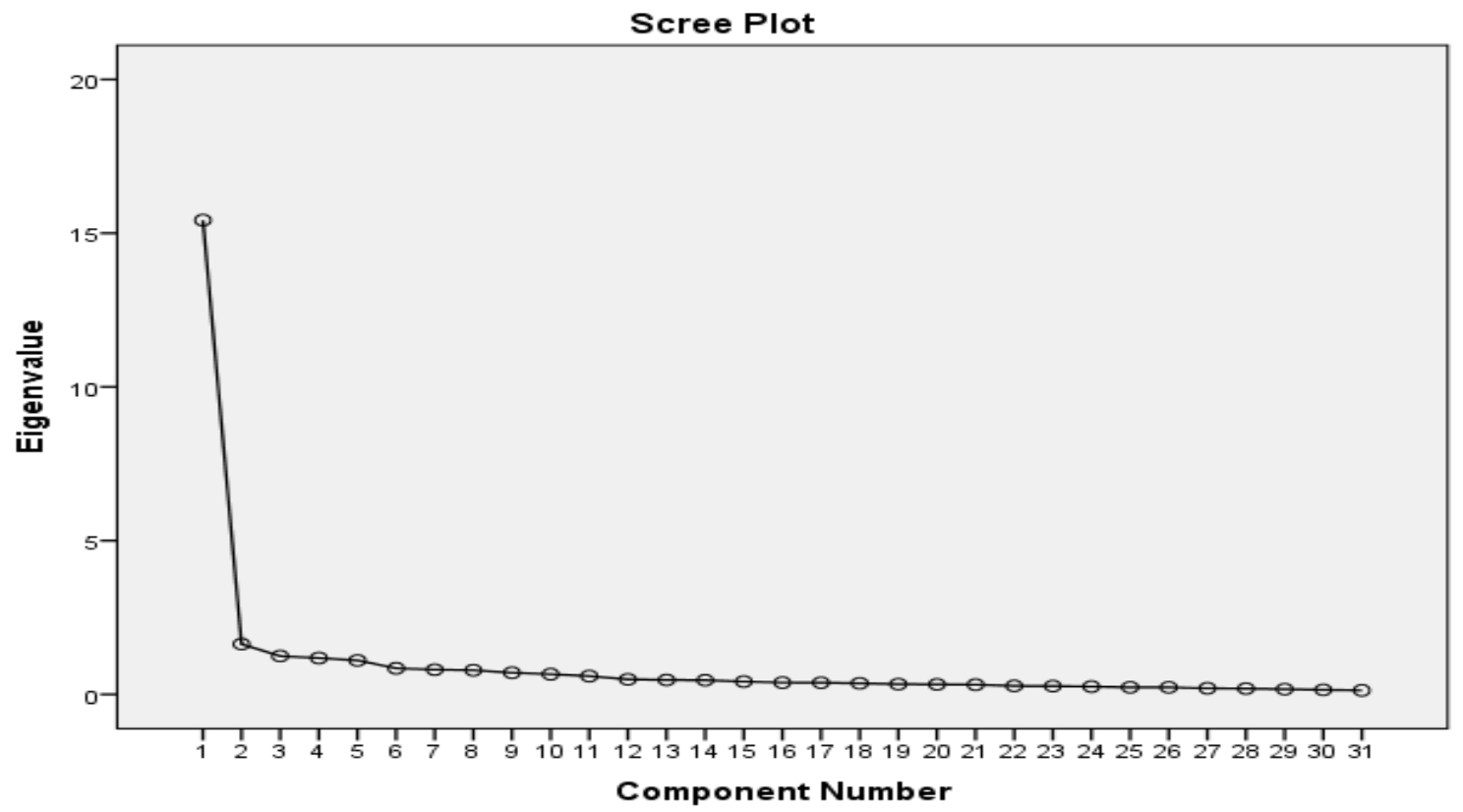

Figure 2: Scree plot for Brand Management Practices

Kaiser-Meyer-Olkin and Bertlet's tests of sampling adequacy results show that the indicators of brand management practices had KMO of 0.954 and there were five critical factors driving the brand management practices which accumulated to 66.421 percent of the total variance in these construct.

The Kaiser criterion has a weakness as observed by Nunny and Berstein (1994) as its tendency to overstate the number of factors. Stevens (2002) proposes the use of a scree plot in determining the number of components to retain when the sample size is greater than 200. The scree plot graphs the eigenvalues against the component number and displays a point of inflexion on the curve, which can be used in determination of number of components to extract. In a scree plot, the components before this point indicate the number of factors to retain while the components after the point of inflexion show that each successive factor is accounting for smaller and smaller amounts of variations hence should not be retained.

According to Norusis (2003), the plot most often shows a distinct break between the steep slope of the large factors and the gradual trailing off of the rest of the factors, the scree that forms at the foot of a mountain. Only factors before the scree begins should be used. The scree plot in Figure 2 shows a point of inflexion after the first component and for this reason only the first component was considered adequate descriptors of the variations in the combined data set.

The results in Total Variance Explained table indicated that factor one had four most dominant loadings which accounted for 49.748 percent of the variance in this construct. Factor 2 contributing 5.276 percent of the variance, factor 3 had $4.018 \%$ of the variance, factor 4 had $3.812 \%$ of the variance while factor 5 had $3.567 \%$ of the variance.

Rotation has the effect of optimizing the factor structure and states the relative importance of the factor. This implies that from the study results, the system has identified five important factors to be loaded in the analysis. From the results in Rotated Component Matrix table rotated matrix, factor one is highly and positively correlated with (University programmes are perceived to be of high quality) BMP14 (.934), (The university enjoys strong heritage/history) BMP5 was highly and positively correlated with factor two (.739), (I understand the management structure of this university) BMP24 was highly and positively correlated with factor five (.739) while (The staff are Down-to-Earth) BMP27 was highly and positively correlated with factor three (.698).

\section{Factor Analysis for Corporate Image}

All the constructs of the corporate image were subjected to factor analysis and the results presented in Table 4.3. 
Table 4: Factor Analysis for Corporate Image

\begin{tabular}{|c|c|c|c|c|c|c|}
\hline \multicolumn{7}{|l|}{ KMO and Ba } \\
\hline \multicolumn{5}{|c|}{ Kaiser-Meyer-Olkin Measure of Sampling Adequacy. } & \multicolumn{2}{|c|}{.956} \\
\hline \multicolumn{2}{|c|}{ Bartlett's Test of Sphericity } & \multicolumn{3}{|c|}{$\begin{array}{l}\text { Approx. Chi-Square } \\
\text { df } \\
\text { Sig. }\end{array}$} & \multicolumn{2}{|c|}{$\begin{array}{c}3698.241 \\
91 \\
.000\end{array}$} \\
\hline \multicolumn{7}{|c|}{ Total Variance Explained } \\
\hline \multirow[b]{2}{*}{ Component } & \multicolumn{3}{|c|}{ Initial Eigenvalues } & \multicolumn{3}{|c|}{ Extraction Sums of Squared Loadings } \\
\hline & Total & $\%$ of Variance & Cumulative \% & Total & $\%$ of Variance & Cumulative \% \\
\hline 1 & 9.062 & 64.729 & 64.729 & 9.062 & 64.729 & 64.729 \\
\hline 2 & .758 & 5.413 & 70.142 & & & \\
\hline 3 & .682 & 4.869 & 75.011 & & & \\
\hline 4 & .496 & 3.541 & 78.552 & & & \\
\hline 5 & .443 & 3.161 & 81.713 & & & \\
\hline 6 & .420 & 2.999 & 84.712 & & & \\
\hline 7 & .371 & 2.652 & 87.364 & & & \\
\hline 8 & .336 & 2.402 & 89.766 & & & \\
\hline 9 & .306 & 2.184 & 91.950 & & & \\
\hline 10 & .278 & 1.988 & 93.938 & & & \\
\hline 11 & .258 & 1.845 & 95.783 & & & \\
\hline 12 & .235 & 1.675 & 97.458 & & & \\
\hline 13 & .191 & 1.367 & 98.825 & & & \\
\hline 14 & .165 & 1.175 & 100.000 & & & \\
\hline
\end{tabular}

Extraction Method: Principal Component Analysis.

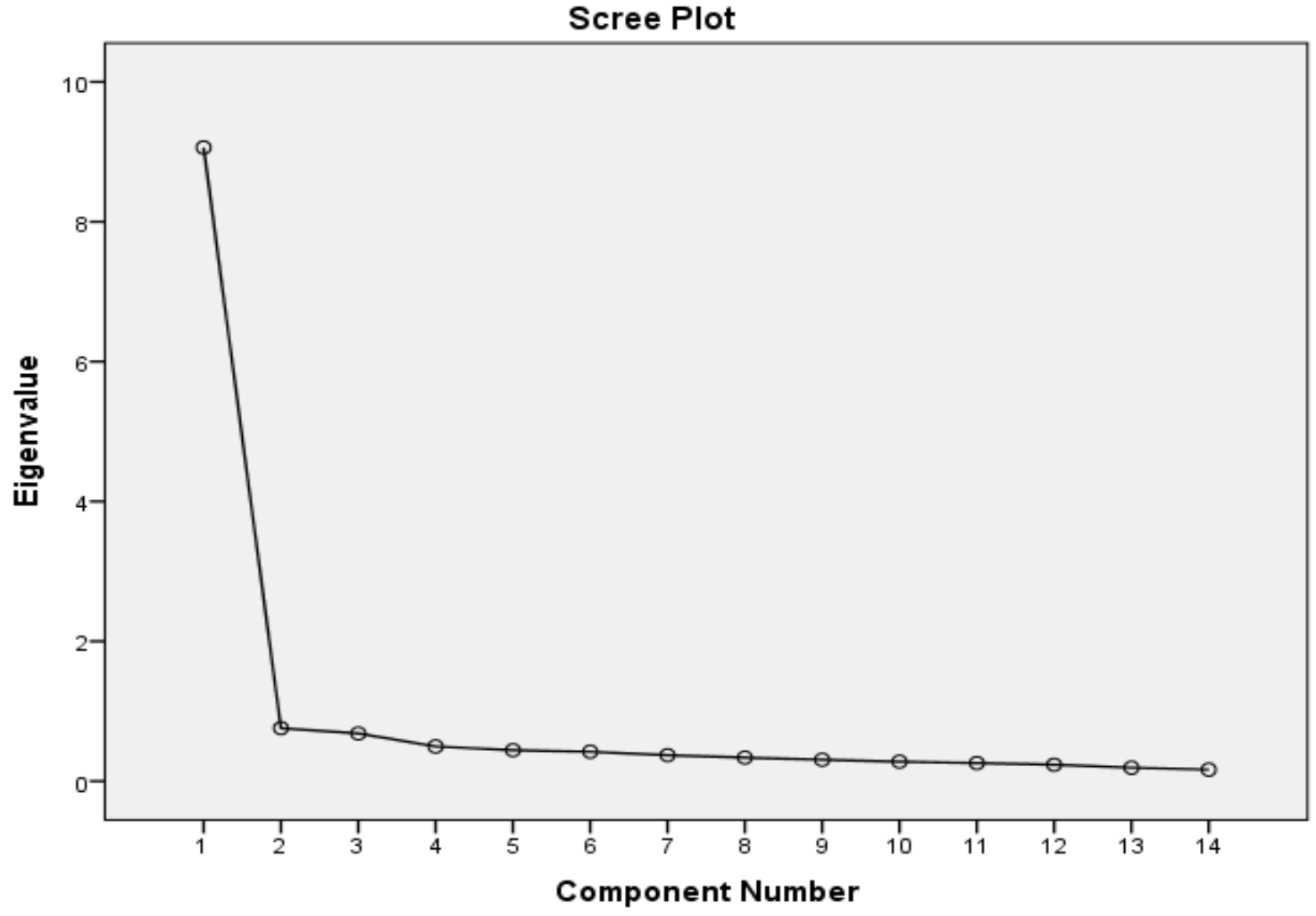

Figure 3: Scree plot for Corporate Image

Kaiser-Meyer-Olkin and Bertlet's tests of sampling adequacy results show that the indicators of brand management practices had KMO of 0.956 and there was one critical factor driving the corporate image which accumulated to 64.729 percent of the total variance in these construct.

The Kaiser criterion has a weakness as observed by Nunnally and Berstein (1994) as its tendency to overstate the number of factors. Stevens (2002) proposes the use of a scree plot in determining the number of components to retain when the sample size is greater than 200 . The scree plot graphs the eigenvalues against the 
component number and displays a point of inflexion on the curve, which can be used in determination of number of components to extract. In a scree plot, the components before this point indicate the number of factors to retain while the components after the point of inflexion show that each successive factor is accounting for smaller and smaller amounts of variations hence should not be retained.

According to Norusis (2003), the plot most often shows a distinct break between the steep slope of the large factors and the gradual trailing off of the rest of the factors, the scree that forms at the foot of a mountain. Only factors before the scree begins should be used. The scree plot in Figure 3 shows a point of inflexion after the first component and for this reason only the first component was considered adequate descriptors of the variations in the combined data set.

Rotation has the effect of optimizing the factor structure and states the relative importance of the factor. This implies that from the study results, the system has identified one important factors to be loaded in the analysis. From the rotated matrix, factor one is highly and positively correlated with (The university location is convenient) CI4 (.859).

The second objective was to establish the mediating effect of corporate image on the relationship between brand management practices and customer satisfaction among universities in Kenya. In testing for the mediating effect of corporate image on the influence of brand management practices on customer satisfaction, the Baron and Kenny (1986) approach was employed.

The approach known as step wise technique includes a four step process whereby one step evaluates the influence of brand management practices on corporate image. Step two evaluates the influence of corporate image on customer satisfaction among university students in Kenya. Step three evaluates the influence of brand management practices on customer satisfaction among universities in Kenya and the requirement is that this influence should be statistically significant. The influence of brand management practices should be statistically significant when controlling for corporate image for mediation to be confirmed. The direct and indirect effect in testing for the intervening effect was as presented in the path diagram in Figure 5.1.

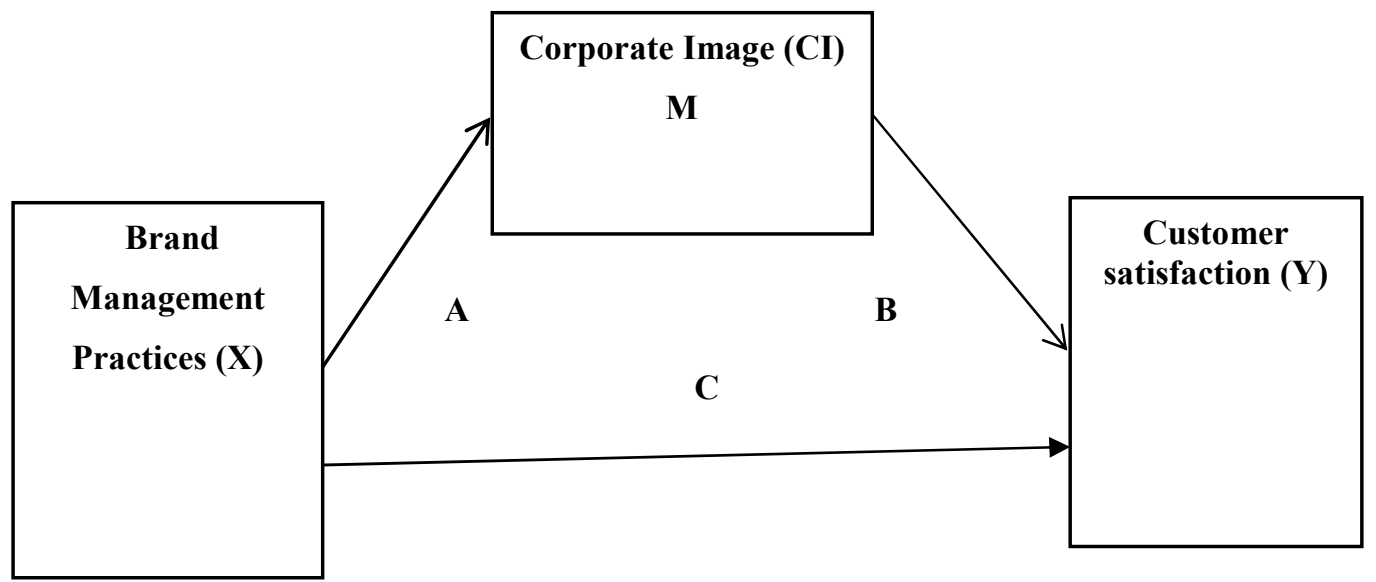

Key: $\mathrm{X}=$ Independent variable; $\mathrm{M}=$ Mediating variable and $\mathrm{Y}=$ Dependent variable

Figure 4: Path diagram for mediation Effect

Source: Baron, R.M., \& Kenny, D. A., (1986). The moderator - mediator variable distinction in social psychological research: Conceptual, strategic and statistical considerations. Journal of personality and social psychology, 51, $1173-1182$.

Path $\mathrm{C}$ represents the direct effect of Brand management practices (BMPs) on customer satisfaction. Path A represents the interaction of Brand management practices (BMPs) and corporate image (CI) which is the indirect effect (intervening) while path B represents the influence of corporate image on customer satisfaction. Paths A and B represent the indirect effect. Step one of the tests for the intervening effect of corporate image and customer satisfaction was performed. This step involved evaluating the influence of brand management practices on customer satisfaction. The requirement is that this influence should be statistically significant. Consequently the influence of brand management practices on customer satisfaction was evaluated while controlling for corporate image. The influence of brand management practices on customer satisfaction should also be statistically significant when controlling for corporate image for mediation to be confirmed. To determine the effect corporate image on the relationship between brand management practices on customer satisfaction among university students in Kenya, regression analysis was conducted and the findings were presented as shown in Table 5.

The results in Table 4.4a) show that brand management practices explains $14.9 \%$ of the variation in customer satisfaction among students in public University $\left(\mathrm{R}^{2}=.14 .9\right)$. The results indicate that the overall model 
is statistically significant at $95 \%$ level of confidence. The first step implies that the relationship between brand management practices and customer satisfaction is positive and statistically significant. The ANOVA results in Table 4.4(b) show a p-value of 0.000 which is less than 0.05 indicating that the model is statistically significant in explaining the impact of the independent variables on the dependent variable.

Regression Results of the Mediation effect

Table 5: Step 1 -Effect of brand management practices on customer satisfaction

5 a) Model Summary - Brand management practices and Customer satisfaction

\begin{tabular}{lrrrrr} 
Model & R & & R Square & Adjusted R Square & $\begin{array}{c}\text { Std. Error of the } \\
\text { Estimate }\end{array}$ \\
\hline 1 & & $.488^{\mathrm{a}}$ & .238 & .236 & 1.007 \\
\hline
\end{tabular}

a. Predictors: (Constant), BMP

Source: Researcher (2018)

5 b) ANOVA

\begin{tabular}{llccccc}
\hline Model & & Sum of Squares & df & Mean Square & F & Sig. \\
\hline 1 & Regression & 114.829 & 1 & 114.829 & 100.815 & $.000^{\mathrm{b}}$ \\
& Residual & 368.004 & 323 & 1.139 & & \\
& Total & 482.833 & 324 & & & \\
\hline
\end{tabular}

a. Dependent Variable: Customer Satisfaction

b. Predictors: (Constant), Brand Management Practices

Source: Researcher (2018)

5 c): Coefficients

\begin{tabular}{|c|c|c|c|c|c|}
\hline \multirow[b]{2}{*}{ Model } & \multicolumn{2}{|c|}{ Unstandardized } & \multirow{2}{*}{$\begin{array}{c}\text { Standardized Coefficients } \\
\text { Beta }\end{array}$} & \multirow[b]{2}{*}{$\mathbf{T}$} & \multirow[b]{2}{*}{ Sig. } \\
\hline & B & Std. Error & & & \\
\hline $\begin{array}{ll}1 & \text { (Constant) }\end{array}$ & 2.339 & .173 & & 13.512 & .000 \\
\hline BMP & .475 & .045 & .488 & 10.643 & .000 \\
\hline
\end{tabular}

a. Dependent Variable: Customer Satisfaction

Source: Researcher (2018)

The results in Table 5 a) show that brand management practices explains $23.8 \%$ of the variation in customer satisfaction among students in public University $\left(\mathrm{R}^{2}=.238\right)$. The results indicate that the overall model is statistically significant at $95 \%$ level of confidence. The first step implies that the relationship between brand management practices and customer satisfaction is positive and statistically significant. The ANOVA results in Table 5(c) show a p-value of 0.000 which is less than 0.05 indicating that the model is statistically significant in explaining the impact of the independent variables on the dependent variable. In the second step, a regression analysis to assess the relationship between brand management practices and corporate image was conducted. In this step, brand management practices were treated as the independent variable and corporate image as the dependent variable. The results are summarized in Table 6.

Table 6: Step 2 - Regression Results of brand management practices and corporate image 6 a) Model Summary

\begin{tabular}{lcccc}
\hline Model & R & R Square & Adjusted R Square & Std. Error of the Estimate \\
\hline 1 & $.553^{\mathrm{a}}$ & .306 & .304 & .999 \\
\hline
\end{tabular}

a. Predictors: (Constant), Brand Management Practices

Source: Researcher (2018)

6 b) ANOVA ${ }^{\text {a }}$

\begin{tabular}{llccccc}
\hline Model & & Sum of Squares & df & Mean Square & F & Sig. \\
\hline 1 & Regression & 159.506 & 1 & 159.506 & 142.289 & $.000^{\mathrm{b}}$ \\
& Residual & 362.182 & 323 & 1.121 & & \\
& Total & 521.688 & 324 & & & \\
\hline
\end{tabular}

a. Dependent Variable: Corporate Image

b. Predictors: (Constant), Brand Management Practices

Source: Researcher (2018)

\section{6 c) Coefficients}

\begin{tabular}{|c|c|c|c|c|c|}
\hline \multirow[b]{2}{*}{ Model } & \multicolumn{2}{|c|}{ Unstandardized Coefficients } & \multicolumn{3}{|l|}{ Standardized Coefficients } \\
\hline & B & Std. Error & Beta & $\mathbf{t}$ & Sig. \\
\hline 1 (Constant) & 1.664 & .172 & & 9.689 & .000 \\
\hline BMPs & .560 & .044 & .553 & 12.644 & .000 \\
\hline
\end{tabular}

a. Dependent Variable: Corporate Image

Source: Researcher (2018) 
The results in Table 6 a) portray that brand management practices explains 30.6 percent of the variation in Corporate Image $\left(\mathrm{R}^{2}=.306\right)$. The overall model results reveals that the relationship among brand management practices and Corporate Image is statistically significant at $\mathrm{a}=0.05(\mathrm{~F}=63.180, \mathrm{p}$-value $=0.000)$. This indicates brand management practices predicts corporate image outcome of the public universities. The beta coefficients also indicate that statistically significant linear relationship between corporate image and brand management practices was detected $(B=0.527, p=0.002)$. The ANOVA results in Table $6(b)$ show a $p$-value of 0.000 which is less than 0.05 indicating that the model is statistically significant in explaining the impact of the independent variables on the dependent variable.

The third step of the test for the intervening effect of corporate image on the relationship between brand management practices and customer satisfaction involved testing the influence of corporate image on customer satisfaction. Finally, the process involved testing for the influence of brand management practices on customer satisfaction while controlling for corporate image. The results for the two steps are presented in Table 7.

Table 7: Step 3 and 4 - Regression Results of moderation effect of corporate image on brand management practices and Customer Satisfaction

\section{7 a) Model Summary}

\begin{tabular}{lcccc}
\hline Model & R & R Square & Adjusted R Square & Std. Error of the Estimate \\
\hline 1 & $.592^{\mathrm{a}}$ & .350 & .349 & .929 \\
2 & $.623^{\mathrm{b}}$ & .388 & .384 & .904
\end{tabular}

a. Predictors: (Constant), Corporate Image

b. Predictors: (Constant), Corporate Image, Brand Management Practices

Source: Researcher (2018)

7 b) ANOVA

\begin{tabular}{llccccc}
\hline & Model & Sum of Squares & df & Mean Square & F & Sig. \\
\hline 1 & Regression & 169.231 & 1 & 169.231 & 174.465 & $.000^{\mathrm{b}}$ \\
& Residual & 313.602 & 323 & .970 & & \\
& Total & 482.833 & 324 & & & $.000^{\mathrm{c}}$ \\
& Regression & 187.104 & 2 & 93.552 & 101.908 & \\
& Residual & 295.729 & 322 & .918 & & \\
& Total & 482.833 & 324 & & & \\
\end{tabular}

a. Dependent Variable: Customer Satisfaction

b. Predictors: (Constant), Corporate Image

c. Predictors: (Constant), Corporate Image, Brand Management Practices

Source: Researcher (2018)

\section{7 c) Coefficients}

\begin{tabular}{|c|c|c|c|c|c|}
\hline \multirow[b]{2}{*}{ Model } & \multicolumn{2}{|c|}{ Unstandardized Coefficients } & \multicolumn{3}{|l|}{ Standardized Coefficients } \\
\hline & B & Std. Error & Beta & t & Sig. \\
\hline 1 (Constant) & 1.968 & .159 & & 12.341 & .000 \\
\hline $\mathrm{CI}$ & .570 & .041 & .592 & 13.996 & .000 \\
\hline (Constant) & 1.595 & .174 & & 9.153 & .000 \\
\hline $\mathrm{CI}$ & .447 & .047 & .464 & 9.406 & .000 \\
\hline BMP & .225 & .048 & .231 & 4.678 & .000 \\
\hline
\end{tabular}

a. Dependent Variable: CS

Source: Researcher (2018)

Key: $\mathbf{B M P}=$ Brand Management Practices; $\mathbf{C I}=$ Corporate Image; and $\mathbf{C S}=$ Customer Satisfaction

At step two, brand management practices, adds significantly to the customer satisfaction as the variation increased from 0.350 to $0.388\left(\mathrm{R}^{2}\right.$ change $=0.038 \mathrm{p}$-value $\left.=0.000\right)$. The results reveal that the variance explained by corporate image is significant $(\mathrm{F}=195.887, \mathrm{p}$-value $=.000)$. The ANOVA results in Table 7 (b) show a p-value of 0.000 which is less than 0.05 indicating that the model is statistically significant in explaining the impact of the independent variables on the dependent variable. The results revealed that the regression coefficients for brand management practices was statistically significant after adding corporate image to the regression implying that corporate may be wielding a complete mediating effect. This implies that changes in corporate image positively affect the brand management practices and customer satisfaction relationship since there was a positive direction in their relationship.

A summary of the mediated regression analysis is presented in Table 8. 
Table 8: Mediating Effect of Corporate image on the Relationship between Brand management practices and customer satisfaction Summary

\begin{tabular}{|c|c|c|c|c|c|}
\hline Analysis & $\mathbf{R}$ & $\mathbf{R 2}$ & $\begin{array}{l}\mathbf{R}^{2} \\
\text { Change }\end{array}$ & B & (p-value) \\
\hline $\begin{array}{l}\text { Analysis one: } \\
\text { Brand Management practices on Customer } \\
\text { satisfaction }\end{array}$ & $.386^{\mathrm{a}}$ & 0.149 & 0.143 & 0.385 & 0.000 \\
\hline $\begin{array}{l}\text { Analysis two: } \\
\text { Brand Management practices on Corporate } \\
\text { image }\end{array}$ & $.559^{\mathrm{a}}$ & .312 & .308 & .527 & 0.000 \\
\hline $\begin{array}{l}\text { Analysis three: } \\
\text { Corporate image on Brand Management } \\
\text { practices and customer satisfaction }\end{array}$ & $.462^{\mathrm{a}}$ & 0.213 & 0.202 & 0.77 & 0.002 \\
\hline
\end{tabular}

Source: Researcher (2018)

The results in Table 8 reveal that the correlation between brand management practices and customer satisfaction was moderate and statistically significant at $\mathrm{p}<.05(\mathrm{r}=.386, \mathrm{p}$-value $=.000)$ while that of brand management practices on corporate image was strong and statistically significant $(r=.559, \mathrm{p}$-value $=.000)$.

The current research findings, presents the regression model that estimated the mediation effect of corporate image on the relationship between brand management practices and customer satisfaction is stated as follows:

$$
C S=2.001+0.442 C I+0.077 B M P+e
$$

Where; CS is the customer satisfaction; BMP is Brand management practices; CI is the Corporate Image

Figure 5: Modified Mediating Effect of Corporate image on the Relationship between Brand management practices and customer satisfaction

Part A: Overall Direct Effect

Path C

$$
\mathrm{R}^{2}=0.386, \beta=0.385, \alpha=2.498
$$

Source: Primary Data.

Part B: Path Diagram for Mediation Effect of Corporate Image

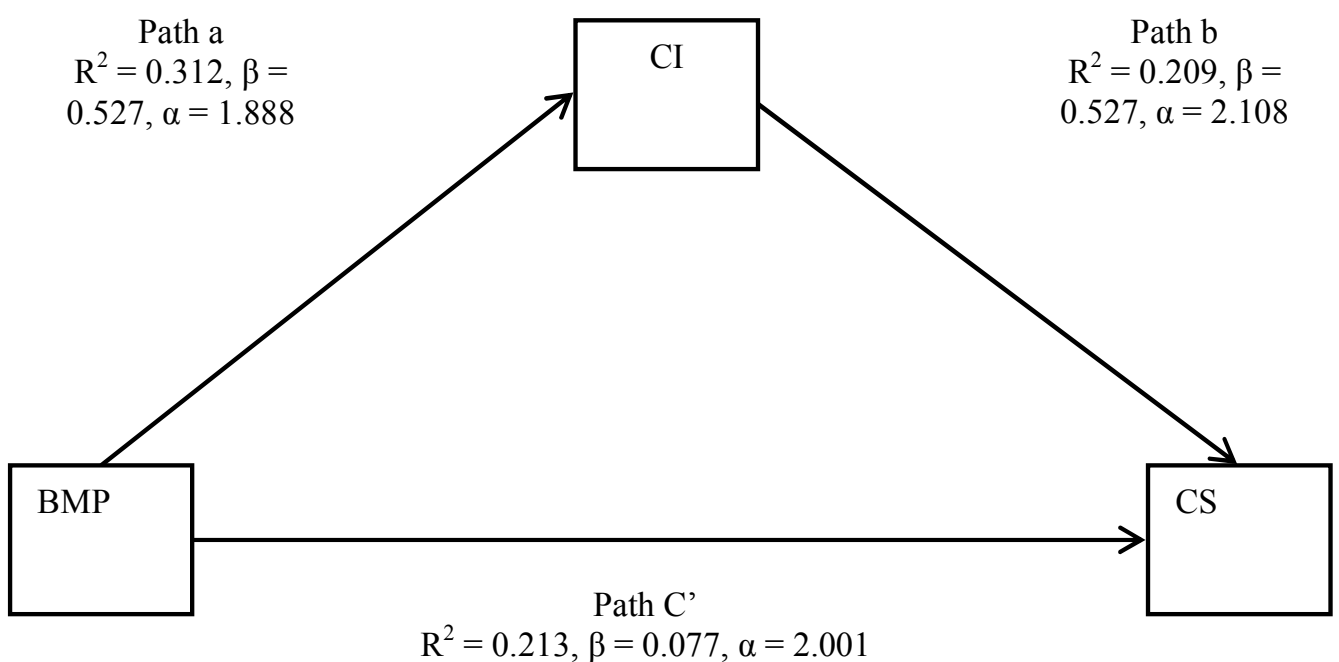

The results in Figure 5 support the hypothesis that brand management practices influences customer satisfaction through routes of intermediate factors. The pertinent results indicated that $\mathrm{R}^{2}$ moved from 0.209 to .213 when corporate image were added (.213-.209=.004). This implied that corporate image explained the additional $0.4 \%$ of the difference in customer satisfaction. Further, the outcome indicates that the effect of brand management 
practices on customer satisfaction in the last major step of the analysis (path c) is statistically insignificant at 0.05 implying complete mediation. This explains the influence of the brand management practices mediated by corporate image.

\section{Summary of Findings and Conclusion}

The principal objective of the study was to examine the influence of brand management practices, corporate image, and customer characteristics on customer satisfaction in universities in Kenya. The specific objectives of the study were to establish the influence of brand management practices on customer satisfaction, to establish the mediating effect of corporate image on the relationship between brand management practices and customer satisfaction, to establish the moderating effect of customer characteristics on the relationship between brand management practices and customer satisfaction and to determine the joint influence of brand management practices, customer characteristics and corporate image on customer satisfaction in universities in Kenya.

The study reveals that brand management practices have significant influence on customer satisfaction among university students in Kenya $\left(\mathrm{R}^{2}=0.238\right.$; $\mathrm{P}$ value $\left.<0.05\right)$. The study also establishes that corporate image has a significant mediating effect on the relationship between brand management practices and customer satisfaction $\left(\mathrm{R}^{2}=0.213\right.$; $\mathrm{P}$ value $\left.<0.05\right)$. An increase in the value of corporate image strengthens the relationship between brand management practices and customer satisfaction.

\section{Limitations of the Study}

The principal purpose of the study was to establish the influence of brand management practices, corporate image, and customer characteristics on customer satisfaction in universities in Kenya. While this objective was achieved, it was not devoid of limitations. It was limited in scope and a number of factors including time and financial constraints. The study used cross sectional survey since it is one of the most appropriate methods available to address both financial and time constraints. Additionally, the use of telephone contacts, coupled with competent research assistants, enhanced response considerably.

\section{Suggestion for Further Research}

This study focused on the customers alone. The value of a brand is determined by all the stakeholders who associate with it. Therefore, the researcher recommends further studies that incorporate all critical stakeholders in the higher education sector in Kenya. These include but not limited to the university employees (both teaching and non-teaching), the management staff, the employers, regulators, among others.

\section{References}

Aaker, D. (1991). Managing Brand Equity: Capitalizing on the value of brand name. New York: The Free Press.

Aaker, J. L. (1997). Dimensions of brand personality. Journal of Marketing Research, 34(3), 347-56.

Andreassen, T. W. \& Lindestad B. (1998). Customer loyalty and complex services: The impact of corporate image on quality, customer satisfaction and loyalty for customers with varying degrees of service expertise, International Journal of Service Industry Management, 9 (1), 7 - 23.

Baron, R. M., \& Kenny, D. A. (1986). The moderator-mediator variable distinction in social psychological research: Conceptual, strategic, and statistical considerations. Journal of Personality and Social Psychology, $51,1173-1182$

Bravo, R., Montaner, T., \& Pina, J. M., (2009). The role of bank image for customers versus non-customers. International Journal of Bank Marketing, 27(4), 315-334.

Jiang, J. J. \& Klein, G. (2009). Expectation-conformation theory: capitalizing on descriptive power. In Dwivedi, Y.K., Lal, B., Williams, M. D., Schneberger, S.L., \& Wade, M. (eds.), Contemporary Theoretical Models in Information Systems (pp. 384-401). Hershey, PA: In-formation Science Reference.

Kandampully, J. \& Hu, H. H. (2007). Do hoteliers need to manage image to retain loyal customers? International Journal of Contemporary Hospitality Management, 19(1), 435-443.

Kapferer, J. N. (2008). Strategic brand management: Creating and sustaining brand equity long term. New Delhi: Kogan Page.

Keller, K. (1993). Conceptualizing, measuring, and managing customer-based brand equity. Journal of Marketing, 57(1), 1-22.

Keller, K. (2001). Building customer-based brand equity: A blueprint for creating strong brands. Marketing Science Institute, 107(1).

Kotler, P. \& Armstrong, G. (2008). Principles of Marketing. New Jersey: Prentice-Hall.

Kotler, P. \& Keller, K. L. (2012). Marketing Management. Upper Saddle River, N.J: Prentice Hall.

Krejcie, R.V., \& Morgan, D.W. (1970). Determining Sample Size for Research Activities. Educational and Psychological Measurement, 30, 607-610

Makgosa, R. \& Molefhi, B. A. (2012). Rebranding an institution of higher education in Botswana. Business and 
Economic Research, 2(2).

Mourad, A. K, Gaese, H. \& Jabarin, S. A. (2010). Economic value of tree fruit production in Jordan Valley from a virtual water perspective, Water Resource Management, 24(1), 2021-2034.

Mourad, M., Ennew, C., \& Kortam, W. (2011). Brand equity in higher education. Marketing Intelligence \& Planning, 29(4), 403-420.

Mugenda, O. M. \& Mugenda, A. G. (1999) Research Methods: Quantitative and Qualitative Approaches. Nairobi, Kenya: Acts Press.

Nguyen, N. \& Leblanc, G. (2001). Corporate image and corporate reputation in customers' retention decisions in services. Journal of Retailing and Consumer Services, 8(4), 227-236.

Norušis, M. J. (2003). SPSS 12.0 Statistical Procedures Companion. Chicago: Prentice Hall.

Nunnally, J., \& Bernstein, I. H. (1994). Psychometric theory. ( $3^{\text {rd }}$ ed.). New York: McGraw-Hill.

Oliver R. L. (1997). Satisfaction: a behavioral perspective on the consumer. New York: Irwin/McGraw-Hill.

Owino, E. (2013). The influence of service quality and corporate image on customer satisfaction among university students in Kenya. (Unpublished PhD Thesis). University of Nairobi, Kenya.

Spreng, R. A., MacKenzie, S. B. \& Olshavsky, R. W. (1996). A reexamination of the determinants of consumer satisfaction. Journal of Marketing, 60(3), 15-33.

Stevens, J. P. (2002). Applied multivariate statistics for the social sciences. (4th ed.). Mahwah, NJ, US: Lawrence Erlbaum Associates Publishers.

Vukasovic, T. (2015). Managing consumer-based equity in higher education. Managing Global Transitions, 13 (1): $75-90$

Waithaka, T. W. (2014). Corporate identity management practices, organizational characteristics, corporate image and brand performance of Kenyan Universities. (Unpublished PhD thesis). School of Business, University of Nairobi, Kenya. 